\title{
Kiai's role as ulama and umara: Implications to the pesantren education
}

\section{Peran kiai antara sebagai ulama dan umara: Implikasi terhadap dunia pendidikan pesantren}

\author{
Ahmad Adi Suradi ${ }^{1 *} \&$ Buyung Surahman ${ }^{2}$ \\ ${ }^{1}$ Department of Islamic Education, Faculty of Tarbiyah, Institut Agama Islam Negeri Bengkulu \\ ${ }^{2}$ Department of Early Childhood Islamic Education, Faculty of Tarbiyah, \\ Institut Agama Islam Negeri Bengkulu \\ Address: ${ }^{1,2}$ Jalan Raden Fatah, Pagar Dewa, Bengkulu 65144 \\ E-mail: suradi@iainbengkulu.ac.id* \& buyungsurahman@iainbengkulu.ac.id
}

\begin{abstract}
This article explains the dualism of the role of kiai pesantren (Islamic boarding school) in Banyuasin Regency, South Sumatera, as ulama and umara, which was later critically elaborated in this research on its implications to the pesantren education. Substantively, this research was inspired by the results of the study of the authors of the 2018 regional elections and ahead of the 2019 elections and presidential elections. The method of this writing can be categorized as qualitative research. The analysis in this paper is carried out on the basis of the concepts of space and field, especially to examine how far the kiai play religious teachings which they believe in social and political behavior in the midst of people's lives. The results of this study indicate that the rise of kiai who are involved in the world of politics is full of intrigue and conflict among kiai-politicians. One important thing revealed in the involvement of kiai in the political world was that kiai were too close to power, so they used the pesantren for their political interests and made it an instrument for power. For a kiai of pesantren plus politicians, they should be able to carry out their two professions sincerely and istiqomah. If not, the influence of the kiai becomes meaningless, when his authority is deemed to have deviated from what he should have. As a result, many pesantren were abandoned and their development was very alarming. Because of differences in perspective in politics that lead to feuds between the interfaith and the pesantren that they foster.
\end{abstract}

Keywords: kiai's role; ulama; umara; pesantren; education

\begin{abstract}
Abstrak
Artikel ini menjelaskan terjadinya dualisme peran kiai pesantren di Kabupaten Banyuasin, Sumatera Selatan, sebagai ulama dan umara, yang kemudian dielaborasi secara kritis terhadap implikasinya di dunia pendidikan pesantren. Secara substantif, artikel ini banyak diilhami oleh hasil studi penulis pemilihan kepala daerah (pilkada) tahun 2018 dan menjelang pemilu serta pemilihan presiden (pilpres) tahun 2019. Metode penelitian ini dapat dikategorikan sebagai penelitian kualitatif. Analisis penelitian ini, dilakukan pada dasar konsep ruang (space) dan medan (field), terutama untuk mencermati seberapa jauh kiai memerankan ajaran agama yang diyakininya dalam perilaku sosial politik di tengah-tengah kehidupan masyarakat. Hasil studi ini menunjukan, bahwa maraknya para kiai yang terjun dalam dunia politik yang sarat dengan intrik dan konflik para kiai-politisi. Satu hal penting terungkap dalam keterlibatan para kiai dalam dunia politik adalah para kiai sudah terlalu dekat dengan kekuasaan, sehingga menggunakan pesantren untuk kepentingan politiknya dan menjadikannya sebagai instrumen bagi kekuasaan. Bagi seorang kiai pesantren plus politisi, hendaknya mampu menjalankan kedua profesinya secara ikhlas dan istiqomah Jika tidak, pengaruh kiai menjadi tidak bermakna, ketika otoritasnya dianggap telah menyimpang dari apa yang seharusnya. Akibatnya banyak pesantren yang terbengkalai dan perkembangannya sangat memprihatinkan. Karena perbedaan cara pandang dalam berpolitik yang menyebabkan perseteruan antar kiai dan antar pesantren yang diasuhnya.
\end{abstract}

Kata kunci: peran kiai; ulama; umara; pendidikan; pesantren

\section{Introduction}

Islamic boarding schools hereafter referred to pesantren, which are often cited as the oldest educational institutions that maintain their traditional values, are not free from the process's reach. Nevertheless, pesantren can maintain their existence as a filter for foreign cultures to continue to 
survive in the modern era. Pesantren's success in the course of their socio-cultural transformation cannot be separated from the leadership role of kiai in them (Mas'ud 2004). Thus, the existence of a kiai as a leader of pesantren is one factor that determines the success of pesantren. Although the kiai became charismatic figures, only a few followers felt compelled to follow the steps of kiai politics. The difference between the kiai and his followers concerning political behavior eventually became a normal phenomenon, especially after the change in Islamic political parties. However, the role of the kiai, in general, is still essential because the kiai is at the forefront of guiding the morality and orthodoxy of Muslims (Maunah 2010).

This reality allows the kiai to contribute significantly to various problems of publicity. The role of the kiai is limited to the spiritual aspects and the broader aspects of social life (Wahid 1987). During the current leadership crisis, both in the system of government and Indonesian state that can be considered not having enough morality, the return of the role of moral figures such as kiai is an answer so that the kiai can not only guard the morality of the people (ummah). However, it also restores politics and education in Indonesia, prioritizing the Indonesian nation's character and morality. The existence of kiai, who are both caregivers and leaders of pesantren in terms of their roles and functions, can be seen as a unique leadership phenomenon. It happens because in addition to a leading pesantren that is not only tasked with compiling curricula, making rules, designing evaluation systems while carrying out teaching and learning processes related to the science of religion, they also act as coaches, educators and community leaders (Sadi 2016).

In the leadership process, there will undoubtedly be a kiai relationship with the community in the pesantren. In everyday life, kiai can provide spiritual motivation to the community to be able to improve performance productivity in order to achieve the goals of the pesantren (Kusmayadi et al. 2016). For example, through taushiyah (normative message) or by using an exemplary approach (uswah). In addition, a kiai as the leader of a pesantren must also be able to interact positively with the community, communicate ideas and formulate the pesantren's vision, and the mission he leads (Sadi 2016). In the last period, the figure of the kiai was and has become a figure who often became the public spotlight in his involvement in politics. Kiai, which has been better known as the successor to Islamic culture, seems to have been eroded by political currents that are far from religious teachings. Both in interpretation and in terms of policies that no longer favor the people (Abdurrahman 2009).

Thus, the relation of kiai to the dynamics of local politics is an interesting study in Islamic political research in Indonesia. A kiai is not interpreted as a person involved in the field of religion alone, but how examine the kiai as a form of social-political power space in society. It then distinguishes the kiai as a scholar (ulama), where ulama focuses on developing religious preaching (syiar). In the sociocultural relations of Muslims in Indonesia, the kiai has a vital position and position in fostering and managing life according to its capacity as the heirs of the prophets (waratsat al-anbiya) (Jati 2012).

This condition then led to a growing assumption in the community in looking at kiai figures when they participated in the political world, which was a condition with intrigue and conflict in it. In the political world, it is sometimes challenging to distinguish who is the mastermind and who is the puppet. Because someone could appear as a puppet, but at other times, it could also appear as a puppeteer or a provocateur. If the political world is in such a way, the problem is; it is appropriate for a religious leader to take part in a political world that seems to have a bad image (Wahid 1987). This shift in the role of the kiai from the scholar (ulama) to government (umara) was later critically elaborated in this paper on its implications in the world of pesantren education. Substantively, this paper inspired by the results of the author's study of the 2018 regional election and ahead of the elections and the 2019 presidential election on the dual role of the kiai; ulama and umara.

\section{Research Methods}

This research categorized as qualitative research, using a phenomenology approach. In addition, in research that uses this phenomenological approach, researchers also involve their perspectives on symbolic interactions. In this case, the researcher seeks to understand the subject of his research 
from the subject itself by not neglecting in making interpretations and making conceptual schemes (Ulfatin 2014). Research on kiai, using various perspectives, has been carried out by experts with different expertise backgrounds. However, the sociological study of the kiai in Banyuasin Regency, South Sumatera, by including the theological background variables they adhere to, as far as they can be found, is still not widely done. The analysis in this paper is carried out based on the concept of space and field, especially to examine how far the kiai play religious teachings in which they believe in social and political behavior in the midst of people's lives. In such a framework, the theological perceptions of the kiai are placed in two spaces, which influence the external space of the Indonesian people and the internal space of each individual. In contrast, the national political phenomenon surrounding the kiai's social life is used to describe the ongoing social field.

\section{Results and Discussion}

\section{Kiai's position: Theory of symbolic interactionism}

The existence of phenomena and social studies of several Islamic leaders in Indonesia shows that the kiai are figures who have a central and strategic position in the community. Therefore, the existence of kiai as pesantren leaders is vital because the success of pesantren lies mostly in the leadership factor of the kiai. The leadership of the kiai in the pesantren, as said by some experts, that almost all leadership in a pesantren is individual, which is very dependent on the charism of the leading kiai in the pesantren (Lubis 2013). However, even so, it cannot merely be called an authoritarian leadership, because the leadership of the kiai has been formed in such a way in accordance with the leadership values exemplified by the Prophet. So if viewed from a religion paternalistic leadership pattern, the pattern of interaction between kiai and community members tends to be familial. By using this religion paternalistic leadership pattern, kiai in interacting with their community becomes close without putting aside the ethics of interaction as they should.

There is a social construction that places kiai as individuals who have moral integrity and always have followers. Social construction like this makes the kiai occupy an elite position within the Muslim community in Indonesia. The existence of kiai in prestigious positions here can be understood and has become a universal law for the needs of central figures in each society (Rasyid 2012). The elite in social action can be implicated in a social change, where the existence of elites is not sufficiently measured by skills, skills, and shrewdness, but seen from the side of morality and the consequences of its struggle. Such as positioning the kiai as the elite of the Nahdhatul Ulama (NU) is associated with the structure of personality, social structure, and cultural structure. The character of a cleric is not only in the pesantren environment but also in the outside environment of pesantren (Abdurrahman 2009).

The existence of the kiai in the study of sociology shows the phenomena of social life paralleled by the theory of symbolic interactionism. Symbolic interactionism is a theory that studies the nature of interactions where it is a dynamic social activity of humans. Herbert Mead and Blumer are figures who developed this theory. In this perspective, there are at least several premises that are understood, namely the meaning of symbols, self, social interaction, and society. In this perspective, individuals are active, reflective, and creative in interpreting, displaying behavior that is complicated and unpredictable. This theory rejects the idea that individuals are passive organisms whose behavior is determined by the forces or structures that exist outside themselves. Because individuals continue to change, society changes through interaction. In essence, it is not a structure of society but an interaction which is considered an essential variable in determining human behavior. Through conversations with others, we are better able to understand ourselves and also a better understanding of the messages we and others send and receive (West \& Turner 2010).

The theory above is associated with the leadership of the kiai regarding the concept of thought and there may be several possibilities when revealing what is done by the kiai who acts as leaders in the pesantren in actualizing their thinking concepts to the pesantren community. Pesantren communities may carry out their duties based on dedication. It dedicates that they are based on commitment and sincerity, or perhaps they carry out pesantren programs that are not based on loyalty and sincerity. 
However, because they are dependent on the kiai who are followed, whether they are dependent on socio-economic status, or even carrying out all activities based on what Weber revealed, they carry out acts of rationality (west rational). Value rationality is an action that is influenced by confidence and interest in a high-value order such as truth, beauty, justice, or belief in God. Thus such beliefs can lead to the emergence of loyalty, obedience, and compliance of the pesantren community.

\section{Leadership and role of kiai}

In the Islamic community, the kiai is one of the elites who have a very respectable position and a significant influence on society's development. The Kiai becomes one of the strategic elites in the community because of his position as a figure who has extensive and in-depth knowledge about Islamic teachings. Moreover, theologically he is also seen as the heir to the Prophets (waratsat al-anbiya). It is not surprising that the kiai then becomes a source of legitimacy for various problems the people face, not only in aspects of religious laws but also in almost all aspects of their lives (Faridl 2003).

This study found some behaviors that exist in the kiai in a pesantren; first, the kiai's were able to make themselves ideal leaders in the eyes of their subordinates through the charisma they had. This charisma is seen in terms of the knowledge possessed by the kiai, both natural and supernatural. Second, as a pesantren leader, the kiai is good at motivating and inspiring his subordinates to have high enthusiasm for developing pesantren. Some strategies carried out by the kiai include: 1) make themselves as the good example (uswatun hasanah) which is suitable for their subordinates, 2) provide rewards for subordinate members who do good work, and 3) always hold introspection (muhasabah) together every month in order to change and improve and make it one of the communication media of the kiai with all of their subordinates. Third, although the kiai is the head of the pesantren, it does not make himself a single authoritarian leader to his subordinates. Because they want an atmosphere of democratic organization, the kiai is also giving their authority to all subordinate members through delegation of tasks. Fourth, as a leader and also a kiai at a pesantren, he can give his attention to his subordinates both individually and together. Individually, this is carried out by the kiai through oneon-one discussion and exchange of ideas regarding both cottage issues and personal issues. $\mathrm{R}$ stated:

"Whereas to give attention to all subordinate members, the kiai always holds a meeting at his residence at the end of each month and holds an event that involves them."

Observing the leadership behavior of the kiai at the place of this study, the researcher identified that the leadership behavior of kiai in pesantren was transformational leadership. Transformational leadership refers to building commitment to organizational goals and trusting followers to achieve these goals. As such, transformational leaders try to make a transforming visionary into a shared vision (leaders and subordinates). Transformational leadership is seen through several leadership behaviors such as idealized influence, inspirational motivation, intellectual stimulation, and individualized consideration (Yulk 2011).

Coulson and Trafford state that transformational education leaders are characterized by the ability of leaders to respond to various challenges, maintain a vision of a right school and achieve it with high energy and commitment, and show personal qualities that refer to moral integrity (Suradi 2017), while, according to Burns (1999), transformational leadership is a process in which leaders and followers raise themselves to a higher level of morality and motivation. In conjunction with Maslow's hierarchy of needs, transformational leaders need to increase the needs of subordinates from the most basic to the peak level of self-actualization (Achidsti 2010). Thus, the leadership behavior of the kiai that leads to transformational leadership can foster enthusiasm in the subordinate members to achieve the pesantren's vision and mission. Because, in transformational leadership, the orientation is to increase subordinates' commitment to achieving goals.

In socio-cultural Muslims, kiai has a vital position and position in fostering and managing life according to their capacity as the heirs of the prophets (waratsat al-anbiya). The meaning of the heirs of the prophet gives legitimacy for the kiai to carry out various tasks, including educating people in 
the field of religion and others, exercising social control over society, solving social problems that occur in society, and becoming cultural brokers, namely becoming agents of social change in society. Through their various roles, both in the religious and socio-cultural fields, the kiai then emerged as patrons who had hierarchical power over society. In terms of political science, kiai's are political actors who have charismatic and traditional political resources that enable them to shape individual political attitudes or preferences in the social structure of the surrounding community (Mulkhan 2009).

This can be reflected in the regional head elections in various regions where the regional head candidates and their representatives went to the pesantren to request the kiai's political blessing to advance in the regional elections in his area. In addition, the kiai were also often consulted by the regional head in taking various important decisions in his government. The blessings and opinions of the kiai are politically interpreted as valid references for regional heads to run the wheels of government (Santoso 2010). The entry of kiai in the political realm can be translated into the Nahdlatul Ulama (NU) organization, where there is a repositioning of the kiai to become scholars. The meaning of the kiai and the ulama needs to be clarified where the ulama plays more administrative functions of bureaucrats and politics, while the kiai tends to play at the cultural level (Faridl 2003). The implication of the transition of kiai to ulama also affected the meaning of the pesantren, which was no longer a religious school for students (santri), but also the pesantren was also symbolized as the epicenter of the power of local politics.

In leading pesantren, the kiai always tries to balance the interaction between the kiai and the pesantren community, both internal teacher communities (ustadz) and student communities (santri) and the external community, through physical interaction, the interaction of mindset, and personal interaction. Thus, both students (santri), teachers (asatidz), staff, and the community can participate in developing pesantren as agents of change in various aspects of life. From various previous data exposures, a pattern of interaction was seen between kiai and santri, asatidz, and the community. In interacting with the santri, the kiai made himself both a teacher and a father to his children, who deserved to be emulated and made a role model. In this case, the kiai conducts physical interaction, which means that they always present themselves in the santri at each event, as well as provide opportunities for educative-democratic interactions for 24 hours. Mostly, in interacting with santri, kiai gives more motivation through mauidhoh hasanah to them to always be passionate in seeking knowledge in pesantren. In addition, the kiai also used the exemplary motivational approach (uswah); for example, the kiai gave an example to his santri by always praying five times in congregation in istiqomah (continual). Therefore, the close interaction between the kiai and the santri shows that the kiai as the pesantren caregivers provide opportunities for the intensification of education.

The interaction of kiai with their subordinates, which includes teachers (asatidz), administrators, and staff, is mostly done through interaction mindset. As a leader in a pesantren, the kiai never ignores the voice that comes from his subordinates, so that in the process of implementing the program in the pesantren, the kiai always invites his subordinates to exchange ideas and discuss in advance. This is one of the building's ongoing interactions to feel part of the pesantren. In addition to interacting with the internal community of pesantren, the kiai interacts with the external community of pesantren, which, in this case, is the community. PPAQ stated:

"Spirit interaction is carried out by the kiai to the community through spiritual activities such as religious events, one of the kiai's media to interact with the community."

In line with, the kiai have a creative role in social change, namely introducing elements of the external system and causing changes in society. The social changes that occur in a pesantren, which then impact society, are positively caused by the role of the kiai actors. The process of this change can be observed in the roles of pesantren in bringing religious messages framed with the existing value systems in society, such as mutual help, courtesy, the spirit of living in business and work and even inviting openness to new things in communities such as technology and globalization (Horikoshi 1990).

The interaction between leaders and subordinates is essential for each organization, including the pesantren organization. Even though the pesantren leadership is a kiai, it does not mean that they 
must close themselves with their subordinates. On the contrary, the kiai must often interact not only with the. Pesantren's internal community but also with the external community of the pesantren. This is similar to interaction theory, which, in principle, is the same as the contingency theory by Fiedler and Ralph M. Stogdill's expectancy-reinforcement theory. This interaction theory assumes that the more frequent interactions and participation in joint activities, the more feelings of mutual affection and the mutual understanding of group norms increase.

\section{The involvement of kiai in practical politics}

Ahead of the general elections and presidential elections in 2019, none of the social institutions were static, including kiai. As a social institution, kiai also experience their dynamics. In the past, almost all kiai were classified as cultural kiai and a good power base. However, now, the emergence of structural kiai and bureaucrats is no longer a foreign item. As the latest phenomenon shows, the kiai 'congregation' has slid onto practical politics. The involvement of kiai in politics seems unavoidable. The position of ulama, who is at the forefront of Islamic society, makes informal leaders who maintain the understanding of Ahlus sunnah wal jama'ah but also political leaders because in Indonesia, the relationship between politics and Islam is firm. The efforts of scholars to develop the Ahlus sunnah wal jama'ah were realized by establishing pesantren as centers of Islamic education. On the other hand, the interests of scholars in politics are realized by their involvement with Islamic political parties (Ridwan 2010).

The phenomenon of differences in socio-political behavior among kiai is, in many ways, influenced by at least two factors. First, the factor of the kiai's social position, which, according to previous studies, shows that there is a driving force for changing society. A study conducted by Horikoshi (1990), for example, shows the strength of kiai as a source of social change, not only in pesantren communities, but also in the surrounding communities, while kiai's as cultural brokers and states that the influence of the kiai lies in the implementation of the broker's function (Kusmayadi et al. 2016). Although politically, the kiai is categorized as having no professional experience and ability, they are socially proven to be able to bridge various interests through the language they are most likely to use. Second, the personal power factor, which is characterized by theological thinking, is based on the behavior it plays. As a figure who is often identified as having charismatic power during the community, kiai's are seen as having 'extraordinary' abilities to mobilize the community, especially in determining political choices. Kiai is not a politician, but his political calculations are often considered the last political 'fatwa' to follow (Faridl 2003).

Thus, the author's argument that the position of the kiai is very strategic can be observed from the social reality in the pesantren tradition. The significant struggles of pesantren in the field of social religion, education, community development, and the political field are mostly in the hands of kiai. The separation of the roles of pesantren and kiai is challenging as both have firm cultural and social relations because the existence of the kiai with a rich tradition and social networks is an important pillar and has contributed to the development of pesantren. The pattern of kinship built by the kiai in the pesantren tradition takes place quite effectively. The pesantren tradition can develop into a social system that influences the wider community. The influence of pesantren with their seniority is not only on socio-religious issues but also on economic and political issues.

The politics of Nahdlatul Ulama (NU), organizationally, and pesantren, is complicated to distinguish. However, both are intuition that stands alone, politically both have a reciprocal relationship, meaning that a pesantren influences the politics of Nahdlatul Ulama residents. Nahdlatul Ulama's policies often influence the political attitudes of pesantren, in which political travel is accompanied by the dynamics of the pesantren's political role. Even the role of kiai pesantren is sometimes the trigger of conflict within Nahdlatul Ulama. Because, in reality, apparent problems are brought into the internal Nahdlatul Ulama. Pesantren are not only able to maintain their existence but also have enthusiasm and consistency in applying their ethos and mission. This kiai pesantren, then, has a considerable influence on their environment, both politically and socially (Umiarso \& Zazin 2011).

The critical side of the existence of the kiai lies in their charisma. Charisma in social studies is difficult to know through definitive traits but can be identified through a series of strong personalities, 
significant influences, diligent, very expressive, courageous, assertive, full of confidence, sociable, high-minded, and energetic (Sulaiman 2011). Charisma itself, according to Ridwan (2010), comes from the breadth of the knowledge of religion, morals, and rhetorical abilities. This charisma ownership makes the kiai able to hold the leadership authority outside the country, which has stable access to influence and mobilization of the masses. In praxis politics, mass is the quantity of voice to reach the peak of power, so it is evident that politicians' interests are to use the charisma of the kiai for their pragmatic political goals.

The logic built by politicians is simple; that is, when they can influence a kiai, they will automatically gain support from the masses possessed by the kiai. However, kiai is not as innocent as politicians think. Instead of politicians influencing the kiai, what happened was just the opposite. According to Antonio in Rasyid, the process of influencing is called hegemony (Rasyid 2012). However, this term is used in a positive sense, not the negative that Gramsci introduced. By hegemony, it is hoped that politicians will follow the morality, views, and values believed by the kiai. Therefore, according to the author, around the social and political role of the kiai in the socio-political field that grows and develops. Especially in our society, it will always involve the intersection of discourse between religion and politics. Besides, the empirical reality also illustrates this combination of religion and politics seen in the roles played by several kiai on the practical political stage for at least the past few decades. Among the social effects of the dual role it creates is a shift in the community's tendency to establish informal leadership figures, especially the kiai.

At the same time, the community still firmly believes that, normatively, the kiai is still seen as charismatic figures who play their social roles significantly. It is still the ultimate source of 'fatwa' when the community is at a crossroads between confusing political choices. On the other hand, the phenomenon of changes in the structure of the kiai's cognition concerning these socio-political roles is closely related to the theological perceptions they hold. Therefore, to understand the attraction between the dual role of the kiai in the range of socio-political and religious life, it cannot be ultimately separated from the effort to trace the theological roots, which become the basic framework of the socio-political behavior that it plays.

\section{Analysis of the practical political implications of kiai to the pesantren education in Banyuasin}

In a democratic society system, anyone has the right to associate and engage in politics. It is just that not all kiai should have politics. If the kiai is very 'innocent' and Sufistic and is seen as more beneficial to the community with the 'independent political movement,' it would be nice to keep in the world of pesantren printing superior Muslim scientists or becoming transformers of society with the seeds of coolness guarding the moral of the nation (Sulaiman 2011).

A kiai plunging or not into politics is entirely dependent on the principle of benefit and resilience in the face of material temptations and hegemony that will lead him. Whether the existence of kiai in political roles can create dynamic harmony and partiality to universal interests, or does the kiai create static disharmony and partisanship of the party or affirmation of personal interests. Political charm sometimes does make someone lose his idealism. In the past, it was possible for someone to refuse and even forbid him to come into contact with politics. However, because there are interests such as material, hegemony, prestige, and the smooth running of the bureaucracy, the involvement of kiai in practical politics is inevitable.

Plunging into politics is indeed a significant gamble, it could be that religion and politics are no longer unifying, but become a factor breaking the unity and brotherhood among Muslims themselves. People and religion will be dragged into the most pragmatic politicization, fall into low politics, and become immoral. As a result, Islam is no longer Islamic and moral examples are no longer found. In fact, in extreme cases, God can be dragged in the low politics arena as justifiers of all actions (Subiyakto 2011).

The opinion of Suradi (2017) seems to need to be contemplated, namely that the kiai may be political (practical) insofar as it is carried out professionally and proportionately. Professional means they 
contain the ability and ethics. Meanwhile, proportional means that, if the kiai takes care of the pesantren or becomes a central figure in routine recitation in the community, the concerned person should be able to share his time well and avoid conflicts of interest. Based on the opinion of Siradj (2017), the kiai at least focuses on a specific vision and mission related to politics, namely how the implementation of the 2018 elections and elections and the 2019 presidential election will be able to run smoothly, peacefully, fairly and democratically and not cause conflict between supporters; one candidate is available. In addition, according to Muhammad (2010), the kiai should consider several essential prerequisites before deciding to engage in politics. First, personal competence, which includes moral integrity and the ability to play politics politely. Second, professional competence rests on the right of the man on the right place (job) or, in the words of the Prophet: if an affair is left to non-experts, then wait for destruction. Third, is the stability and consistency of kiai as cultural brokers and enlighteners.

Two views continue to experience debate about in areas as to where the kiai should play a hegemonic role with practical politics. The first view considers this role to be played outside the fence of practical politics, namely the role of high politics. The reason is related to the position of the kiai, who should transcend themselves above all groups, in addition to the face of the political world of this country, which displays more infected ulcers. As role models, kiai should stand above all political forces and not favor one particular political force. This role will encumber when the kiai has embodied one of the political forces (Mulkhan 2009). This dynamic sparked anxiety for the santri and the appeal for the kiai to return to concentrating onboarding education and optimizing the role of its piety. Indeed, the involvement of kiai in the practical political universe is a classic problem that continues to be a matter of debate. For some circles, however, the involvement of kiai in politics is a necessity that must not be debated because, according to them, Islamic teachings are holistic, not just religion, but religion and government.

For others, the kiai should not enter into practical political puddles, and continue to concentrate on the world of pesantren education. The reason is that the kiai in pesantren education are sacred institutions, a dimension of moral movements that are full of values of sincerity, without tendencies and ambitions, and become the umbrella of all groups (rahmatan lil' alamin). In contrast, politics is profane, which necessitates the existence of tendencies and momentary interests and has a narrow struggle orientation only for certain groups, namely the supporting masses. The phenomenon of candidate pairs and candidates from the group of scholars and religious leaders has become a trend in the reform era that has marked the reopening of democratic crises in Indonesia after a long time in 'suspended animation'. Since then, because there are opportunities and opportunities for scholars to become politicians or bureaucrats, many kiai and ulama who relapse experience' political lust'. Until now, many religious leaders and scholars had 'erected' political power.

The kiai who are political are feared to be trapped in political logic manipulating their base society for the sake of momentary politics, which, in turn, leads to the logic of power, which tends to be cooperative, hegemonic and corrupt. As a result, the power of logic possessed by the kiai, such as the logic of morality, which emphasizes the sincerity of service to the pesantren, will be reduced or even completely lost, defeated by the logic of power. So that causes a feud between the interfaith and the pesantren that they foster. Ideally, the community leaders, including the kiai, are not directly involved in practical politics. They are enough as national teachers who are always ready to be asked for advice and fatwas. Their partisanship is one political party, mainly active, which will reduce preaching ( $d a^{\prime}$ wah) access to the broader community.

Lately, there has been a phenomenon that kiai are used as bridges or stepping stones to be elected as legislators or elected to hold political positions, starting at the national, provincial, and district levels. Ambitions are okay, but it would be nice if someone who intended to have a scholarship for a kiai from the beginning could be istiqomah, which could be consistent with his initial intentions. However, many kiai are happy with such positions. When the NU residents' attention and energy were absorbed into the political world, it was suspected that many Islamic scholars and caregivers of 
the pesantren were not giving enough attention to the pilgrims and pesantren they were leading. As a result, there were many pesantren and madrassas, whose development was very alarming. Political polarization, differences in perspectives in politics, also leads to antagonistic and the inter-Islamic feuds which they foster. They are both citizens in particular and Muslims in general.

\section{Conclusion}

The empirical reality has pointed to the increasing prevalence of the kiai involved in politics, but the wise step to take is to return to the kiai concerned and whether, in politics, the kiai's can minimize the intrigue and conflicts that often occur in it. One important thing that should be contemplated is the involvement of religious leaders in the political world. If a kiai is too close to power, it is feared that he will use the pesantren for his political interests. The Pesantren Qadratullah in Banyuasin and religion can function as instruments for power. For a kiai pesantren plus politicians, they should be able to carry out their two professions sincerely and istiqomah. If not, the influence of the kiai becomes meaningless when his authority is deemed to have deviated from what he should have. As a result, many pesantren were abandoned, and their development was very alarming.

\section{References}

Abdurrahman (2009) Fenomena kiai dalam dinamika politik: Antara gerakan moral dan politik. Karsa 15 (1):25-34.

Achidsti S (2010) Nahdlatul Ulama dalam konflik, tradisi, dan rekonsiliasi. Fikra 1 (3):23-34.

Faridl M (2003) Peran sosial politik kiai di Indonesia. Mimbar 19 (2):198-201.

Horikoshi H (1990) Kyai dan Perubahan Sosial. Jakarta: LP3ES.

Jati WR (2012) Ulama dan pesantren dalam dinamika politik dan kultur Nahdlatul Ulama. Ulul Albab 13 (1):95-111. http://doi.org/10.18860/ua.v0i0.2377.

Kusmayadi E, Agung S, \& Andrias MA (2016) Model kepemimpinan politik kyai: Studi peran kyai dalam pergeseran perilaku politik massa NU PKB dan PPP. Politika 7 (2):21-33.

Lubis SA (2013) Konseling Islami: Kyai \& Pesantren. Yogyakarta: Elsaq Press.

Mas'ud A (2004) Intelektual Pesantren: Perhelatan Agama \& Tradisi. Yogyakarta: LKIS.

Maunah B (2010) Tradisi Intelektual Santri. Yogyakarta: Teras.

Muhammad (2010) Nahdlatul Ulama dan perubahan budaya politik di Indonesia. Jurnal el- Harakah $12(1): 57-65$.

Mulkhan AM (2009) Politik Santri: Cara Merebut Hati Rakyat. Yogyakarta: Kanisius.

Rasyid H (2012) Bimbingan Ulama; Kepada Umara dan Umat. Jakarta: Pustaka Beta.

Ridwan (2010) Kyai dan politik. Swara Politika 10 (2):125-133.

Sadi H (2016) Kiai dan politik: Mengintip motif kiai NU (Nahdlatul Ulama) dalam Pemilu 2009 di Glenmore Kabupaten Banyuwangi. Khazanah Pendidikan 10 (1):123-130.

Santoso P (2010) In The name of democracy: Commoditization of religions by political parties in Indonesia. Journal of Indonesian Islam 4 (1):91-108. http://doi.org/10.15642/JIIS.2010. 4.1.91-108.

Subiyakto R (2011) Keterlibatan kiai dalam Pilkada (Studi kasus Pilkada di Kabupaten Banjarnegara tahun 2006). Jurnal Ilmu Politik dan Ilmu Pemerintahan 1 (1):41-50.

Sulaiman I (2011) Masa Depan Pesantren: Eksistensi Pesantren di Tengah Gelombang Modernisasi. Malang: Madani.

Suradi A (2017) Islamic education in facing the phenomena of globalization: Epistemological perspective of Islamic education philosophy. Al-Idarah 7 (II):47-59.

Ulfatin N (2014) Metode Penelitian Kualitatif di Bidang Pendidikan. Malang: Bayumedia Publishing. 
Umiarso \& Zazin (2011) Pesantren di Tengah Arus Mutu Pendidikan: Menjawab Problematika Kontemporer Manajemen Mutu Pesantren. Semarang: Rasail Media Group.

Wahid A (1987) Principle of Islamic Boarding School Education, the Impact of Islamic Boarding School in Education and Community Development in Indonesia. Berlin: Technical University Berlin.

West R \& Turner LH (2010) Pengantar Teori Komunikasi: Analisis dan Aplikasi, ${ }^{\text {th }}$ Edition. Translate: Maria Natalia Damayanti Maer. Jakarta: Salemba Humanika.

Yulk G (2011) Kepemimpinan dalam Organisasi, $5^{\text {th }}$ Edition. Jakarta: Rajawali Press. 